\title{
THE EDUCATIVE PRACTICE OF PROFESSIONAL CAREGIVERS AT SHELTERS: COPING WITH VIOLENCE LIVED BY FEMALE ADOLESCENTS
}

\author{
Lucia Helena Garcia Penna ${ }^{1}$ \\ Joana Iabrudi Carinhanha ${ }^{2}$ \\ Ligia Costa Leite ${ }^{3}$
}

\begin{abstract}
Penna LHG, Carinhanha JI, Leite LC. The educative practice of professional caregivers at shelters: coping with violence lived by female adolescents. Rev Latino-am Enfermagem 2009 novembro-dezembro; 17(6):981-7.

This study aimed to identify strategies caregiving professionals at shelters discuss and use in care delivery to violence situations lived by female adolescents; and to discuss educative practice as a care technology for coping with violence. Based on qualitative research, the data were produced through interviews with caregivers at a municipal adolescent shelter and were interpreted according to content analysis. The results evidenced individual and institutional strategies for care delivery to the adolescents. In conclusion, educative actions are care technologies in the reframing process of life's value by female adolescents living on the streets or in shelters, considering the cultural diversity - a dialogical action systemized and institutionalized for coping with the violence they experience.
\end{abstract}

DESCRIPTORS: violence against women; adolescent institutionalized; homeless youth; health education; comprehensive health care

\section{LA PRÁCTICA EDUCATIVA DE CUIDADORES PROFESIONALES EN REFUGIOS PARA NIÑAS: ENFRENTANDO LA VIOLENCIA VIVIDA POR MUJERES ADOLESCENTES}

Este estudio tuvo como objetivo identificar las estrategias discutidas y utilizadas por los profesionales cuidadores de refugios para niñas en la atención a las situaciones de violencia, vividas por las adolescentes, y discutir la práctica educativa como una tecnología de cuidado en el enfrentamiento de la violencia. Con base en la investigación cualitativa, los datos fueron producidos a través de entrevistas a cuidadores de un refugio municipal para adolescentes e interpretados bajo el marco teórico del análisis de contenido. Los resultados evidenciaron estrategias individuales e institucionales para atender a las adolescentes. Se concluye que las acciones educativas son tecnologías de cuidado en el proceso de dar un nuevo significado al valor de la vida para las adolescentes en situación de vivir en la calle o como refugiadas en abrigos, considerando la diversidad cultural - una práctica dialógica sistematizada e institucionalizada para el enfrentamiento de la violencia vivida.

DESCRIPTORES: violencia contra la mujer; adolescente institucionalizado; jóvenes sin hogar; educación en salud; atención integral de salud

\section{A PRÁTICA EDUCATIVA DE PROFISSIONAIS CUIDADORES EM ABRIGOS: ENFRENTANDO A VIOLÊNCIA VIVIDA POR MULHERES ADOLESCENTES}

Este estudo objetivou identificar estratégias discutidas e utilizadas pelos profissionais cuidadores de abrigo na atenção às situações de violência, vividas pelas adolescentes, e discutir a prática educativa como tecnologia de cuidado no enfrentamento da violência. Com base na pesquisa qualitativa, os dados foram produzidos através de entrevistas a cuidadores de abrigo municipal para adolescentes e interpretados à luz da análise de conteúdo. Os resultados evidenciaram estratégias individuais e institucionais para o atendimento das adolescentes. Concluindo, ações educativas são tecnologias de cuidado no processo de ressignificação do valor da vida pelas adolescentes em situação de rua ou abrigadas, considerando a diversidade cultural - uma prática dialógica sistematizada e institucionalizada para o enfrentamento da violência vivida.

DESCRITORES: violência contra a mulher; adolescente institucionalizado; menores de rua; educação em saúde; assistência integral à saúde

${ }^{1}$ RN, Ph.D. in Women's Health and Child, Professor Adjunto, Faculdade de Enfermagem Raquel Haddock Lobo, Universidade do Estado do Rio de Janeiro, Brazil, e-mail: luciapenna@terra.com.br. ${ }^{2}$ RN, Master's Student, Faculdade de Enfermagem Raquel Haddock Lobo, Universidade do Estado do Rio de Janeiro, Brazil, e-mail: iabrudi@yahoo.com. ${ }^{3}$ Ph.D. in Communication, Researcher, Faculty, Instituto de Psiquiatria, Universidade Federal do Rio de Janeiro, Brazil, email: ligialeite@invenciveis.com. 


\section{INTRODUCTION}

Adolescents living on the streets and/or in shelters experience violence in a wide range of aspects: ranging from structural and invisible violence, characterized by abandonment by the family and the State, associated with personal and conjunctural unemployment difficulties, to visible manifestations like physical aggression, sexual abuse, psychological violence, negligence, maltreatment ${ }^{(1-2)}$. Vulnerability to health problems appears in psychoactive drugs abuse, early pregnancy, abortion, physical aggression, unsafe sexual relations ${ }^{(3-4)}$. This reveals the relevance and particularity of violence in restricting the exercise of citizenship by adolescents living on the streets and/ or in shelters and how it makes their health vulnerable.

Based on Paulo Freire's ideas on problematizing education ${ }^{(5-6)}$, one can understand that this is a matter of recovering citizenship, based on a process of self-awareness creation and one's insertion in the world, as a possibility to transform the reality of vulnerability. This problematizing focus is appointed as the fundamental pillar for educative practices that intend to transform, that is, which are capable of breaking with established practices ${ }^{(7)}$ - the denial of these adolescent women's rights. In this sense, shelters, which welcome these adolescents and are characterized as institutions that facilitate the social reinsertion process, should constitute a favorable scenario for a critical and transforming educative process.

Caregiving professionals in shelters, in turn, can exercise a beneficial function as educators in the process of working with the manifestations of violence experienced by these adolescents living on the streets and/or in shelters. However, difficulties to interpret young people's reality, so different from our way of acting, exposes these professionals to emotional exhaustion, which interferes in their ability to act.

The Ministry of Health recognizes the common efforts of different social sectors and public policies with a view to reflections and actions to cope with violence, particularly against women and adolescents. In this sense, investments have been made in training services to diagnose cases of violence and promote adequate care, through the Technical Standard for the Prevention and Treatment of Health Problems Resulting from Sexual Violence against Women and Adolescents ${ }^{(8)}$. That policy values welcoming, adherence strategies and the consolidation of effective approaches, stimulating the search for ways to understand the demands and expectations of female adolescents who experience violence, as well as to contribute to their personal strengthening, helping them to cope with the conflicts and problems inherent in that situation, which demands professionals with technical-scientific knowledge and sensitivity. The answer to violence should be accompanied by an intersectorial discussion process that can help to make the problem more visible and permits the establishment of wider-ranging strategies.

Nursing studies on professionals' work in care delivery to children and adolescents in violence situations are in course, revealing a route filled with insecurity, but also success and investments, such as the inclusion of the theme into academic nursing education ${ }^{(9-13)}$. With a view to contributing to the focus on care delivery to adolescents living on the streets, and its implications for nursing care, in this research, the authors considered that daily discussions among professionals working in shelters for female adolescents about their practice can help them to reflect on educative strategies directed at developing their citizenship, favoring their coping with violence. The following guiding question was used: what educative actions by care professionals at shelters can be appointed as care technologies in coping with violence experienced by adolescents living on the streets? Thus, the following goals were set: to identify the strategies care professionals at shelters discuss and use in care delivery to the situations of violence experienced by the sheltered adolescents, and to discuss educative practice as a care technology to be used for coping with the violence these sheltered young women experience, from the perspective of care professionals at the shelter.

\section{METHOD}

This qualitative research looks into the meanings, subjectivities and values present in the daily reality of a team of professional caregivers at a shelter for adolescents.

The study context was an institution that is part of the municipal shelter network in Rio de Janeiro and is located in the city center. The shelter is a halfway house that welcomes adolescents living on the streets, 
that is, who are distanced from their families for different reasons, ranging from intra-family violence to poverty and risk in the community.

Care professionals in shelters who deal directly with female adolescents can act as educators in the process of dealing with the manifestations of violence these girls experience. Thus, the social protagonists of this research were eight care professionals at the shelter under analysis. The team consists of technicians (professionals with a higher education degree) and educators (professionals with a secondary education degree). Considering the distinguished functions of these professionals in are delivery to the adolescents, the researchers attempted to obtain information from both categories, so as to more fully capture the strategies used by the team. Moreover, the number of subjects was delimited by data saturation, so that four technicians and four educators constituted the social protagonists of this research.

Data were produced in November and December 2007, based on semistructured interviews and interpreted according to thematic content analysis (14). Therefore, the statements were subject to floating reading, outlining excerpts whose meaning was pertinent for the study theme (registration units). The registration units were grouped into categories, depending on the proximity of the meaning they contained. Based on this technique, the shelter professionals' educative practice was analyzed in a critical and transforming perspective, based on the theoretical concepts of Paulo Freire.

While developing this research, all ethical and scientific requirements for research involving human beings were complied with. Approval was obtained from the Research Ethics Committee of the Rio de Janeiro Municipal Health Secretariat (CEP/SMS/RJ), registered under Protocol No. 203/07.

Professional caregivers in coping with violence adolescents live in street situations - a dialogical action with care technology in shelters

Care professionals at the shelter appoint some difficulties to address coping with violence situations experienced by the adolescents, which are many. The histories of most girls are cruel and mobilize professionals, whose statements clearly reveal the need for support, ranging from material to emotional aspects. They indicate that, in most situations, they do not feel able to administer cases that are considered more difficult, in which violence appears in a more pronounced and explicit way.

As for the caregivers' being and living, their powerlessness towards so many situations of injustice, violence and inequality generates a state that destroys, paralyzes and martyrs the being ${ }^{(15)}$. It is also added, however, that this is not permanent and that, as caregivers, they are driven towards another dimension of being and living. This care is based on profound respect for life, in its most different forms of expression, which means "prioritizing new forms of conscience, with a view to the necessary transformations in the quality of being and living in the world", implying the "socialization of power and privileges and the increasing complexity of quality of life for everybody" (15). This contains the bridge that joins care and education, both of which demand forms of cooperation, involvement and mutual support so that, in a dialogical action, growing awareness of the world, the unveiling of the "why" and the "how" of the experienced reality flourish ${ }^{(6,15)}$. As seen next, in the appointed strategies, care and education move together in the professionals' statements, however, perhaps without great awareness of this transforming potential.

Professionals mention that this is an almost solitary struggle. On the one hand, they feel the weight that the families cannot handle the adolescents, indicating that they also need support in all senses. On the other hand, intersectorial work, which should compose an effective support network, happens in function of the professionals' personal characteristics, their engagement and commitment with a view to the establishment of a productive partnership, and does not effectively represent an institutional strategy yet. [...] it is strongly connected with a personhood, it is not a policy. [...] It will depend on the person you are going to meet [...] who is the doctor, for example, who is going to deliver care, what teacher is that. They are going to meet people who are excellent, who do look at them as citizens, that they are capable, that they are people with great things, and they will be looked at from another perspective than 'Ah, there is nothing else to do for this kid' (Interviewee 3).

In view of the daily reality, in their statements, care professionals at the shelter present some strategies used to cope with the violence experienced by the sheltered adolescents. Two types of strategies could be identified and grouped: individual and institutional. 
Individual strategies refer to welcoming the adolescents during talks, when professionals attempt to offer advice related to the demands they observed or which the adolescents themselves put forward, such as: adaptation of speech, financial organization, personal appearance, social rules. I used to do a simulation, 'before going [to the training interview], you are going to come here. Come here ready and I am going to simulate an interview with you'. The clothes they used were inappropriate for an interview, it was a girl with a short skirt, a tight blouse... they got ready, but in their own way. Then I talked to them [...] I used material 'Invest in your Personal Marketing' about good appearance, that some clothes are appropriate for one place and others for another, those clothes were not for an interview [...] shorts, short skirts are very nice to use during funk dance parties, to go to the beach or at your home when you'll be able to go back, but not in here (Interviewee 1).

Reflecting on the meaning of the orientations the professionals provide at the shelter is fundamental. Care is due so as not to make the mistake of providing orientations to the adolescents, as opposed to constructing knowledge with the adolescents, as a drive towards transformation. Great attention is needed as, in the attempt to 'help', it is easy for professionals to set social rules, limits and ways of living they and society consider correct, but which can cause distancing from the adolescents, as they do not truly consider their histories and experiences. Hence, an oppressive context is being reproduced unknowingly. Professionals need to awake to a strategic planning of their activities, systemizing actions based on a critical reflection about the reality of female adolescents living on the streets and/or in shelters.

Although the professionals' statements refer to constant formal training, it is perceived that the care strategies they use are based on an important personal perspective, which determines the way adolescents are addressed and handled, in line with their affinities, skills, postures and, mainly, personal values. Each [professional] has a strategy: some talk a lot, others are their favorite educators. There's that really strict attitude [...]. Some conquer the adolescents with external activities. Some organize soccer games [...] and they talk during the game (Interviewee 1).

Care presupposes the relation between human beings (caregiver and care receiver) and challenges the ability to use these relations as technology that constructs a daily reality, through mutual cooperation between the subjects, either through language, the body, interactions or the ability to see and feel the world ${ }^{(16)}$. Professionals need to perceive that their attitudes and discourse produce effects that can be devastating or constructive in other people, as indicated in this statement: ...when a girl comes here and I say like: 'come here I want you to meet here, she's going to meet a street girl'. My statement is producing a subjective assessment of her - an assessment of 'garbage', that's what I'm producing (Interviewee 3).

The professional caregivers' work with the adolescents, in general, including violence situations, involves the common attitude of respect for the adolescent and dialogue. These are important educative actions that demand closer attention. Dialogue is understood as communication between subjects ${ }^{(6)}$. It is through co-work in dialogical action that subjects problematize oppression with a view to liberation. Therefore, dialogue does not impose, does not handle, does not tame, does not sloganize, but dissolves the myth, unveils reality which, when problematized, challenges the subject who looked at it. Hence, this is about human, sympathetic, loving, communicating, humble and transforming action.

That is how dialogical action takes place, considered as the way of providing human beings with means to overcome their naive and ignorant attitudes of the true oppression human beings themselves live in. As care professionals at the shelter say: ...I attempt to do the work together with them, everything I'm going to do, not do it for me, do what I think, but always talking to them: 'what do you think we can do?'. [...] It's not based on my viewpoint, what I think should be done. I'm always talking to them and presenting the situation (Interviewee 2).

Although they identify the complexity of the violence context the adolescents are inserted in, professionals need to be better equipped to deal with these experiences that are so often trivialized but, at the same time, are concerning and mobilizing, and an institutionalized and systemized support network is needed (intersectorial, interdisciplinary).

Based on the adolescents' welcoming, the professionals identify the problems and, then, use institutional strategies to face them: forwarding and external activities. There are different types of forwarding (health services, schools, professionalization courses, professionalization traineeships), in line with the adolescents' demands, but without any intersectorial relation and follow-up of the adolescent's social insertion process. [...] forwarding to the health station, forwarding to school. There is 
individual care but, when we perceive a different issue, we forward the girl to the Leila Diniz [a municipal project against abuse and sexual exploitation] (Interviewee 1).

Despite the shelter's partnership with different public and private institutions, no network is constituted - considered a dynamic structure in which its members share common values and goals in a communication process ${ }^{(17)}$. A study ${ }^{(18)}$ on violence prevention networks found that the main difficulties for network activities are: different understandings, political divergences, personal ostentation, role conflicts between member entities, professional rotation, different work rhythms, incompatibility of reference frameworks for life and difficulties to include the family in violence protection and prevention actions.

The precarious nature of this systemization permits the emergence of more personal than professional actions involving the adolescents, that is, there is a possibility of diagnostic assessments, forwarding and professional conducts weakly based on justifications, which can originate almost random references to the partners that could constitute a support network. However, the support network is established in a dialectic way. Hence, the following question should be asked: what is the role of shelter professionals and external service professionals in the establishment of this network?

On the other hand, the team's discourse reveals valuation of professional conduct when forwarding, which is identified as a strategy to cope with problem and/or violence situations.

Professionals, however, do not attribute the same value to their orientations - educative actions - as to their forwarding actions. In other words, it is as if they did not perceive dialogue and listening as valuable procedures, as educative actions. Action only seems to be effective when it takes the form of forwarding, with an immediate, concrete response and not as a human development process, constructed in life, based on relations in the world and with the world. This motivation to value forwarding can be interpreted by the difficulties to deal with the situations of these adolescents' lives, including their constant and intensive demand for a rapid solution to their problems. Moreover, some professionals do not have the skills to understand the gradual and slow transformation process deriving from educative actions and choose forwarding as an immediate response action. In most cases, this is not about devaluing the educative action, but about the limitations and demands of the constructed system itself, which is maintained by many segments.

External activities, in turn, are an institutional strategy based on the shelter's partnership with other spaces of leisure and culture (theatre, sports court, cultural centers, museums, beaches, parks), where the adolescents' contact with people is promoted, as well as their circulation through places they usually do not have contact with. There is a project to take them to different places, places everybody goes to. Once we took them to the Botanic Garden (Interviewee 2).

When professionals propose to show the adolescents another form of insertion in society, they are offering them the opportunity to search the 'why' and the 'how' of the reality they experience. This is a good example of how educative actions constitute a singular strategy in care, understood as "a form of creating, it is a possibility of intervening and transforming the situations"(16).

Any human being is considered capable of capturing the data of reality, configuring a knowledge that is nevertheless naive, that is, with minimal apprehension of the causality of the situations experienced (19). However, by constructing the interconnections between the perceived facts, young people living on the streets, as opposed to what some people might think, are fully capable not only of talking about, but also of criticizing their reality, hence, helping to construct authentic care that leads them to selfknowledge, self-care and re-establishment of their health.

Thus, this is about valuing the importance of professionals at the shelter for care delivery to female adolescents living on the streets, by helping them to restandardize the model they have learned, that is, by helping them to break with the repetition of these expected standards. This change can be promoted through courageous education, which allows man to adopt "a new posture towards the problems of his time and space. The posture of intimacy with them. The posture of research instead of simple, dangerous and boring repetition of extracts and assertions disconnected from their actual living conditions"(5).

\section{CONCLUSIONS}

The shelter care professionals' establishment of strategies to cope with violence situations the adolescents experience reveals their involvement with 
these girls' situation. In these relations, educative and care giving potential is found in each professional. True efforts are made to put in practice initiatives that favor social insertion, from the adolescents' as well as society's perspective. It is perceived, however, that the perspective of traditional education and some prejudiced values still guides their daily practice to a significant extent. Hence, there is a need to rescue and raise these professionals' awareness as to the relevance of dialogical actions, proposing and supporting training, recycling and continuing awareness creation, so as to favor and equip these professionals to cope with violence or even with other forms of adversities these girls may experience.

Children and young people living on the streets are a historical reality in Brazil, as well as their institutionalization, considered as an attempt to control these persons who supposedly represent a threat to society. Despite the conquests made as from the Statute of the Child and Adolescent, many barriers remain to establish welcoming which can effectively promote their social reinsertion, based on dialogical action that situates them as subjects and citizens. Establishing a care proposal, free from value judgments, which considers the possibility of a different life story, understanding their roots, which does not expect to confirm sanctioned stigmas and labels for this group, but which accepts and respects their forms of seeing and being in the world and affectionately helps them to overcome the disbelief in themselves. Although they indicate attempts to promote dialogical care, care professionals at the shelter under analysis still remain immobile in view

\section{REFERENCES}

1. Carinhanha JI, Leite LC, Penna LHG. "Minha arma é a mão": a violência como forma de resistência. In: Leite LC, Leite MED, Botelho AP, organizadoras. Juventude, desafiliação e violência. Rio de Janeiro (RJ): Contra-capa; 2008. p. 141-54

2. Phebo L. Vigilância em Saúde e a violência contra adolescentes. In: Taquette SR, organizadora. Violência contra a mulher adolescente / jovem. Rio de Janeiro (RJ): EdUERJ; 2007. p. 31-4.

3. Gomes R. A violência enquanto agravo à saúde de meninas que vivem nas ruas. Cad Saúde Pública 1994; 10(Suppl 1): $156-67$

4. Medeiros M, Ferriani MGC, Munari DB, Gomes R. A sexualidade para o adolescente em situação de rua em Goiânia. Rev Latino-am Enfermagem 2001 março/abril; $9(2): 35-41$. of such adverse and victimizing situations like those lived by the adolescents, which reflect a broader, wrongful and violent social order, about which they feel equally oppressed and, therefore, incapable of acting towards change.

Although hardcore professionals were found who are dedicated to care for these young girls, the need was perceived to invest in these caregivers' training, so as to potentiate their ability as educators, as facilitators of the resignification process of the value of life, of strengthening their self-esteem. It is a difficult process that also slips over the obstacles imposed by the public education, health, economic policy system itself, which does not offer resources for this purpose. On the other hand, possible interventions in the relational sphere need to be strengthened through reflection and discussion on these professionals' daily praxis, so as to produce truly dialogical actions, mobilizing the transformative potential of professionals and adolescents.

Dialogical actions are recognized as fundamental care technologies in the awareness creation process of young women living on the streets or at shelters, with respect to their reality, the acknowledgement of their health rights, their needs, arousing them to the search for quality of life, health promotion and disease prevention (self-care). However, this cannot be a routine practice of adapting the adolescents to social standards in force. Instead, it should be more critical, reflexive, systemized and institutionalized dialogical action, so as to cope with the violence the adolescents experience - a proposal recognized as care.

5. Freire P. Educação como prática da liberdade. 30a ed. Rio de Janeiro (RJ): Paz e Terra; 2007.

6. Freire P. Pedagogia do oprimido. 46a ed. Rio de Janeiro (RJ): Paz e Terra; 2005.

7. Batista N, Batista SH, Goldenberg P, Seiffert O, Sonzogno MC. O enfoque problematizador na formação de profissionais da saúde. Rev Saúde Pública 2005; 39(2):231-7.

8. Ministério da Saúde (BR). Prevenção e Tratamento dos Agravos Resultantes da Violência Sexual contra Mulheres e Adolescentes: norma técnica. $2^{a}$ ed. Brasília (DF): Ministério da Saúde; 2005.

9. Algeri S, Souza LM. Violência contra crianças e adolescentes: um desafio no cotidiano da equipe de enfermagem. Rev Latinoam Enfermagem 2006; 14(4):625-31.

10. Roque EMST, Ferriani MGC. Desvendando a violência doméstica contra crianças e adolescentes sob a ótica dos operadores do direito na comarca de Jardinópolis-SP. Rev Latino-am Enfermagem 2002 junho; 10(3):334-44. 
11. Vendruscolo TS, Ferriani MGC, Silva MAI. As políticas públicas de atendimento à criança e ao adolescente vítimas de violência doméstica. Rev Latino-am Enfermagem 2007 outubro; 15(spe):812-9.

12. Roque EMST, Ferriani MGC, Silva MAI. Intrafamily violence and justice. Rev Latino-am Enfermagem 2007 agosto; 15(4):549-55.

13. Nunes CB, Sarti CA, Ohara CVS. Conceptions held by health professionals on violence against children and adolescents within the family. Rev Latino-am Enfermagem 2008 fevereiro; 16(1):136-41.

14. Bardin L. Análise de Conteúdo. Lisboa: Edições 70; 2000.

15. Silva AL. Céu e inferno: metáforas no processo de cuidar entre os cuidadores. In: Arruda EM, Gonçalves LHT, organizadoras. A enfermagem e a arte de cuidar. Florianópolis (SC): UFSC; 1999. p. 247-65.

16. Nunes DM. Cuidado, um espaço de criação. In: Arruda EM, Gonçalves LHT, organizadoras. A enfermagem e a arte de cuidar. Florianópolis (SC): UFSC; 1999. p. 99-106.

17. Castells M. A sociedade em rede. São Paulo (SP): Paz e Terra; 2000.

18. Njaine K, Assis SG, Gomes R, Minayo MCS. Redes de prevenção à violência: da utopia à ação. Ciênc Saúde Coletiva 2007; 11 Suppl:1313-22.

19. Freire P. Conscientização: teoria e prática da libertação: uma introdução ao pensamento de Paulo Freire. 3a ed. São Paulo (SP): Centauro; 2006. 